\title{
An Empirical Study on Impact of Bilateral Exchange Rate to Trade between Shandong Province of China and Japan
}

\author{
Ping $\mathrm{LI}{ }^{*}$ \\ ${ }^{1}$ Economics and Management College, Weifang University, Weifang, Shandong, China
}

\begin{abstract}
This study explores the impact of bilateral exchange rate on the export and import between Shandong province of China and Japan under supply chains and vertical integration cooperative pattern from regional view. Based on the data over 1998-2017 periods, ADF test, Engle-Granger (EG) test and Granger Causality Test are employed. The results indicate that bilateral exchange rate (RMB/100Yen) is positive to the export trade from Shandong province to Japan, but there is no evidence bilateral exchange rate has effect on the import of Shandong province from Japan. The supply chains and vertical integration cooperative pattern are used to explain the result
\end{abstract}

\section{INTRODUCTION}

With the development of global economy integration, world trade has grown rapidly. Many factors influencing trade balance, including exchange rate, have draw great attention. The nexus between exchange rate variability and international trade has been studied immensely. Empirically, the trade literature carries arguments both for and against currency devaluation, and the empirical results from all these studies are inconclusive.

Trade patterns in East Asia since the 1990s are characterized mainly by supply chains and vertical integration across countries. Particularly, China and Japan, have been recognized as the leading countries representative of this trade structure in the region[1]. Shandong province of China has relatively closer economy ties to Japan owing to the close geographical factor. The main goods exported from Shandong to Japan are final consumer products, but the main imported are Semi-finished products or parts for further processing production. Under supply chains and vertical integration cooperative pattern, the effects on trade brought by bilateral exchange rate are not clear.

China's share of world trade is at the top, and China also have vast trade with Japan. The influence on trade brought by bilateral exchange rate is a research worthy issue. Instead of study the whole country, this paper chose only one province of china, which has the closest economy relationship with Japan due to the special geographical factor and closer economy ties. The aim is to explore the relationship of trade and bilateral exchange rate from a regional view.

\section{Literature review}

K. Doroodian (1999) studied three developing Asian countries and found significant inverse relationship between exchange-rate volatility and international trade[2].

A. Z. Baharumshah (2001) found that the real effective exchange rate is an important variable in trade balance equation and devaluation improves trade balances of both Malaysia and Thailand in long-run [3].

H. Wong (2017) studied the impact of exchange rate volatility on bilateral exports and found there is some evidence of exchange rate volatility to have significant impact on real total exports in the long run. The impact of exchange rate volatility differs across bilateral exports. The impact of exchange rate volatility on exports can be negative or positive[4].

Rose and Yellen (1989) employed co-integration techniques to test the long-run relationship between the trade balance and the real effective exchange rate. but they reported the absence of a long-run relationship between the two variables[5].

Though studies are replete on the exchange-rate variability and trade link, inconclusiveness still prevails in the literature. The main reasons might be the different methodologies applied to address this issue, the different economy situation and the different closeness of subjects studied.

This study applies standard ADF test, Engle-Granger regression based co-integration approach and Granger Causality Test method to provide empirical evidence on the trade response to exchange rate variability of the trade between Shandong province of china and Japan standing on the point of regional economy.

\section{Data choose}

The standard time series during 1998-2017 of Shandong Province of China on import and export have been used and all original data comes from Shandong Provincial 
Bureau of Statistics net. In order to maintain comparability, the import and export data is transferred into RMB according the prevailing conversation rate. To eliminate influence brought by price, all data have been adjusted based on 1995 constant price index. So, we got time series EXP and IMP. RATE represents the bilateral exchange rate between RMB YUAN and Japan Yen (RENMINBI YUAN/100 Japan YEN).

The logarithmic transformation of the initial variables has been applied to this analysis to eliminate heteroscedasticity likely existed. Finally, we got the time series LNEXP, LNIMP and INRATE donating the export of Shandong province to Japan, the import of Shandong province from Japan and the exchange rate between RENMINBI YUAN and Japan Yen (Yuan/100Yen). The applied software is Eviews3.1. Co-integration test of variables and Granger Causality Test

\subsection{Unit Root Test}

In order to avoid spurious regression in the analysis of non-stationary time series, the unit root test is made before Co-integration analysis with ADF Test and the result shown in Table1.

Table 1. Augmented Dickey-Fuller Unit Root Test Result (ADF test)

\begin{tabular}{c|c|c|c|c|c}
\hline Var. & $\begin{array}{c}\text { Test } \\
\text { Type } \\
(\mathrm{C}, \mathrm{T}, \mathrm{K})\end{array}$ & $\begin{array}{c}\text { ADF } \\
\text { Test } \\
\text { Stat. }\end{array}$ & $\begin{array}{c}5 \% \\
\text { Critical } \\
\text { Value }\end{array}$ & $\begin{array}{c}10 \% \\
\text { Critical } \\
\text { Value }\end{array}$ & $\begin{array}{c}\text { Conclu } \\
\text { sion. }\end{array}$ \\
\hline $\begin{array}{c}\text { LNE } \\
\text { XP }\end{array}$ & $(\mathrm{C}, \mathrm{T}, 1)$ & -2.8215 & -3.6920 & -3.2856 & $\begin{array}{l}\text { Unit } \\
\text { Root } *\end{array}$ \\
\hline $\begin{array}{c}\text { LNIM } \\
\text { P }\end{array}$ & $(\mathrm{C}, \mathrm{T}, 3)$ & -1.5823 & -3.6920 & -3.2856 & $\begin{array}{l}\text { Unit } \\
\text { Root } *\end{array}$ \\
\hline $\begin{array}{c}\text { LNR } \\
\text { ATE }\end{array}$ & $(\mathrm{C}, \mathrm{T}, 1)$ & -2.4511 & -3.6920 & -3.2856 & $\begin{array}{l}\text { Unit } \\
\text { Root } *\end{array}$ \\
\hline $\begin{array}{c}\text { DLN } \\
\text { EXP }\end{array}$ & $(\mathrm{C}, \mathrm{T}, 0)$ & -6.2538 & -3.6920 & -3.2856 & Sta. ** \\
\hline $\begin{array}{c}\text { DLNI } \\
\text { MP }\end{array}$ & $(\mathrm{C}, \mathrm{T}, 0)$ & -6.2538 & -3.6920 & -3.2856 & Sta.** \\
\hline $\begin{array}{c}\text { DLN } \\
\text { RATE }\end{array}$ & $(0,0,1)$ & -3.0112 & -1.9627 & -1.6262 & Sta.** \\
\hline $\begin{array}{c}\text { EXPR } \\
\text { ID }\end{array}$ & $(0,0,3)$ & -2.1127 & -1.9644 & -1.6056 & Sta.** \\
\hline $\begin{array}{c}\text { IMPR } \\
\text { ID }\end{array}$ & $(0,0,0)$ & -2.3188 & -1.9602 & -1.6251 & Sta.** \\
\hline
\end{tabular}

Note: $\mathrm{C}, \mathrm{T}$ and $\mathrm{K}$ in test type $(\mathrm{C}, \mathrm{T}, \mathrm{K})$ denotes intercept, trend and the lagged difference respectively. *donates acceptance of hypothesis of a unit root.**donates rejection of hypothesis of a unit root.

From the results: at $5 \%$ significance level, the ADF Test Statistics at level of time series LNEXP, LNIMP and LNRATE are higher than their critical values, but the first-order difference of time series DLNEXP, DLNIMP and DLNRATE are lower than their critical values respectively. Comprehensively, all of the three time series are stationary I (1) process.

\subsection{Co-integration test of variables}

For the two-variables co-integration test, the E-G twostep method is widely used[6]. The E-G test for cointegration is a two-step residual-based test. First, regress the long run equilibrium model of two time series and the residuals are calculated. Then, Proceed with a unit root test on the residuals to test whether the residuals are $\mathrm{I}(0)$. If the residuals are stationary, the two series are co-integrated.

\subsubsection{Co-integration test of LNEXP and LNRATE}

Regress the long run equilibrium model of LNEXP vs. LNRATE and the result is as the following:

LNEXP $=3.183168$ LNRATE

$$
\mathrm{T}=(43.45680)
$$

Then to check whether the residual series (named as EXPRID) is a stationary $\mathrm{I}(0)$ series with ADF method and the result shows in table1. The ADF Test Statistic 2.112729 is smaller than -1.964418 , the Critical Value at $5 \%$ significance level. So the time series LNEXP and LNRATE are co-integrated.

\subsubsection{Co-integration test of LNIMP and LNRATE}

Regress the long run equilibrium model of LNIMP vs. LNRATE and the result is as follows:

LNIMP $=2.766792$ LNRATE

$$
\mathrm{T}=(42.84521)
$$

The ADF method is applied to check the residual series (named as IMPRID), the result showed in table1. At 5\% significance level, time series LNIMP and LNRATE are co-integrated, too.

\subsection{Granger Causality Tests}

The Granger causality test is a useful device to determine whether the lags of one variable contribute to the better forecasting of another variable.

\begin{tabular}{|c|c|c|c|}
\hline Null Hypothesis: & Obs & F-Statistic & Probability \\
\hline $\begin{array}{l}\text { DLNRATE does not Grange } \\
\text { Cause DLNEXP }\end{array}$ & 16 & 5.4924 & 0.02017 \\
\hline $\begin{array}{l}\text { DLNEXP does not Granger Cause } \\
\text { DLNRATE }\end{array}$ & 16 & 3.7534 & 0.05349 \\
\hline $\begin{array}{l}\text { DLNRATE does not Grange } \\
\text { Cause DLNEXP }\end{array}$ & $\left.\right|_{17}$ & 3.4671 & 0.06480 \\
\hline $\begin{array}{l}\text { DLNEXP does not Granger Cause } \\
\text { DLNRATE }\end{array}$ & 17 & 7.8663 & 0.00656 \\
\hline $\begin{array}{l}\text { DLNRATE does not Grange } \\
\text { Cause DLNIMP }\end{array}$ & $\mid 16$ & 0.6498 & 0.64987 \\
\hline $\begin{array}{l}\text { DLNIMP does not Granger Cause } \\
\text { DLNRATE }\end{array}$ & 16 & 0.11260 & 0.11260 \\
\hline $\begin{array}{l}\text { DLNRATE does not Grange } \\
\text { Cause DLNIMP }\end{array}$ & $\mid 17$ & 0.09083 & 0.91379 \\
\hline $\begin{array}{l}\text { DLNIMP does not Granger Cause } \\
\text { DLNRATE }\end{array}$ & 17 & 0.74499 & 0.49547 \\
\hline
\end{tabular}

Table 2. Pairwise Granger Causality Tests

Note: DLNRATE represents the difference between LNRATE and LNRATE(-1).

According to the Granger causality test results in table 2, the null hypothesis that DLNRATE does not Granger 
Cause DLNEXP is rejected at the 5\% level of significance, this finding suggests that DLNRATE does Granger Cause DLNEXP, that is bilateral exchange rate is the Granger Causality of the export of Shandong province to Japan. But the bilateral exchange rate is not the Granger Causality of the import of Shandong province from Japan.

\section{Data analysis}

From the Granger causality test results, the export of Shandong province to Japan is indeed affected by bilateral exchange rate. The positive coefficient of LNEXP in the regression equation of LNEXP and LNRATE indicates that the export of Shandong province to Japan and bilateral exchange rate (RMB/100Yen) are positively correlated, that is, the devaluation of RMB is beneficiary to the export of Shandong province to Japan. The coefficient of LNIMP in the co-integrating equation is positive, which means that bilateral exchange rate has caused increase on the import of Shandong province from Japan. But, Granger causality test result shows that bilateral exchange rate is not Granger causality of the import of Shandong province from Japan. Thus no evidence support the relationship between the two variables.

\section{Conclusion and explanation}

Based on the data of Shandong province in china over the 1998-2017 periods, this paper examines the impact of bilateral exchange rate on the trade between Shandong province and Japan. The co-integration equation indicates that bilateral exchange rate has caused increase on the export of Shandong province to Japan. But there is no evidence that the bilateral exchange rate has effect on the import of Shandong province from Japan.

Japan is a developed country, but china is a developing country. Since the reform and openness to the outside, enormous FDI has come into this country, and Shandong province has become the most favorite region for Japanese direct investment in China. The main imported from Japan to Shandong province are Semifinished products or parts for further industrial processing production. Most of the finished final products through processing trade are sold in the world scope including China. Which means the imported from Japan are less to be affected by bilateral factors and can explain why we can draw such conclusion that there is no evidence that the bilateral exchange rate has effect on the import of Shandong province from Japan. The main goods exported from Shandong to Japan are final consumer products which are more likely being affected by bilateral exchange rate through price adjustment mechanism.

\section{References}

1. M.J. Choi., G.Y. Kim, J. Y. Lee, Emerging Markets Finance \& Trade, 54 pp:1635-1652, (2018)
2. K. Doroodian, J. of Asian Econ. pp. 465-474, 10(1999)

3. A. Z. Baharumshah, Asian Econ. J. Vol. 15 Issue 3, pp. 291-300, 9(2001)

4. H. Wong, Empirical Econo. Vol. 53 Issue 2, pp.459492. 9(2017)

5. A.K. Rose, J. L. Yellen, J. of Monetary Econ., 24, pp. 53-68, (1989)

6. L.Y. Liu, Modern Econ., pp.16-22, 3( 2012) 